J. Gen. Appl. Microbiol. Vol. 9, No. 4, 1963.

\title{
BACTERIAL ACCUMULATION OF RIBOSE AND RIBOSE-5-PHOSPHATE
}

\author{
TAKEO SUZUKI, NOBUMASA TANAKA, FUSAO TOMITA, \\ KUNIZO MIZUHARA and SHUKUO KINOSHITA \\ Tokyo Research Laboratory, Kyowa Hakko Kogyo Co., Ltd. \\ Machida, Tokyo \\ Received November 2, 1963
}

Comparatively little is known about the accumulation of ribose or ribose5 -phosphate (R-5-P) in broth cultures of microorganisms.

In the fermentation broth of an unidentified bacterium using a medium containing glucose, yeast extract, urea and minerals, a significant accumulation of $\mathrm{R}-5-\mathrm{P}$ or ribose was observed. As shown in Table $1, \mathrm{R}-5-\mathrm{P}$ is accumulated in the broth as much as $7 \mathrm{~g}$ per liter. Ribose or $\mathrm{R}-5-\mathrm{P}$ was

Table 1. Production of ribose and ribose 5-phosphate.

\begin{tabular}{|c|c|c|c|c|c|}
\hline & & \multicolumn{2}{|c|}{ 3rd day } & \multicolumn{2}{|c|}{5 th day } \\
\hline \multicolumn{2}{|c|}{$\begin{array}{c}\text { Metal concentration } \\
\%\end{array}$} & Ribose & $\mathrm{R}-5-\mathrm{P}$ & Ribose & $\mathrm{R}-5-\mathrm{P}$ \\
\hline None & - & - & 4.8 & - & 7.4 \\
\hline $\mathrm{Fe}^{++}$ & 0.05 & 0.7 & - & 1.2 & - \\
\hline $\mathrm{Mn}^{++}$ & 0.0005 & 1.5 & - & 1.9 & - \\
\hline$"$ & 0.005 & 2.4 & - & 3.8 & - \\
\hline " & 0.05 & 3.6 & - & 5.2 & - \\
\hline " & 0.1 & 3.0 & - & 3.4 & - \\
\hline " & 0.5 & - & - & - & - \\
\hline $\mathrm{Co}^{++}$ & 0.05 & - & - & - & - \\
\hline $\mathrm{Cu}^{++}$ & " & - & - & - & - \\
\hline $\mathrm{Zn}^{++}$ & " & + & - & + & - \\
\hline $\mathrm{Mo}^{++}$ & $" \prime$ & - & - & - & - \\
\hline $\mathrm{Pb}^{++}$ & " & - & - & - & - \\
\hline $\mathrm{Hg}^{++}$ & " & - & - & - & - \\
\hline $\mathrm{Ni}^{++}$ & " & - & - & - & - \\
\hline
\end{tabular}

Medium composition:

glucose $10 \%$, yeast extract $1 \%$, urea $0.6 \%, \mathrm{KH}_{2} \mathrm{PO}_{4} 1.0 \%$,

$\mathrm{K}_{2} \mathrm{HPO}_{4} 1 \%, \mathrm{MgSO}_{4} \cdot 7 \mathrm{H}_{2} \mathrm{O} 1.0 \%, \mathrm{CaCl}_{2} \cdot 2 \mathrm{H}_{2} \mathrm{O} 0.01 \%$.

Ribose and R-5-P were determined by the modified method of J. B.

Pridham (1), and also by the orcinol- $\mathrm{HCl}$ method after the treatment by anion exchange resin. 
identified by conventional analytical methods and compared with authentic samples of the Nutritional Biochemical Corporation. The following characteristics were examined: Rf values by several paper chromatograms, colorimetric determination of ribose and phosphorus, optical rotations, melting points of ribose and its $p$-bromophenylhydrazone and the release of ribose and phosphate by 5'-nucleotidase of wheat germ.

In order to promote the efficiency of $\mathrm{R}-5-\mathrm{P}$ production, the effects of heavy metal ions in the medium were examined. These experiments showed that most metal ions tested were markedly inhibitory to $\mathrm{R}-5-\mathrm{P}$ production. However, in the presence of $\mathrm{Mn}^{++}$ion, ribose instead of $\mathrm{R}-5-\mathrm{P}$ accumulated in amounts reaching to ca. $5 \mathrm{~g}$ per liter. These results are summarized in Table 1. Heavy metal ions such as $\mathrm{Fe}^{++}$and $\mathrm{Zn}^{++}$exhibited actions similar to $\mathrm{Mn}^{++}$, but they were less effective.

On the other hand, when $\mathrm{Mn}^{++}$was added after $24 \mathrm{hr}$ of cultivation, $\mathrm{R}-5-\mathrm{P}$ accumulated instead of ribose. These results suggest that $\mathrm{Mn}^{++}$ion affects the sugar metabolism at a comparatively early stage of the fermentation. However, much remains to be studied on the function of $\mathrm{Mn}^{++}$in the sugar metabolism of this organism.

Furthermore, another phosphoric acid ester of ribose was detected in the fermentation broth in the absence of $\mathrm{Mn}^{++}$and identified as phosphoribosyl pyrophosphate (PRPP) by paper chromatography.

It is, therefore, presumed that $\mathrm{R}-5-\mathrm{P}$ production may have a close relationship to PRPP which is a key intermediate in nucleotide biosynthesis.

The authors wish to express their thanks to Mr. K. Ohashi and Mr. K. Ogawa for their assistance during the course of this work.

\section{REFERENCE}

(1) Pridham, J. B.; Anal. Chem., 28, 1967 (1956). 